\title{
LIVER TRANSPLANTATION IN EUROPEAN PATIENTS WITH THE HEPATITIS B SURFACE ANTIGEN
}

\author{
Didier Samuel, M.D., Rainer Muller, M.D., Graeme Alexander, M.D., Luigi Fassati, M.D., \\ Béatrice Ducot, M.D., Jean-Pierre Benhamou, M.D., Henri Bismuth, M.D., \\ and the Investigators of the European Congerted Agtion on Viral Hepatitis Study*
}

\begin{abstract}
Background. The role of liver transplantation in patients positive for the hepatitis B surface antigen (HBsAg) is controversial because of the high rate of recurrent hepatitis B virus (HBV) infection. It has not been determined whether this risk is greater for certain patients and whether the administration of anti-hepatitis $B$ surface antigen (anti-HBs) immune globulin is beneficial.

Methods. We conducted a retrospective study at 17 European centers of 372 consecutive HBsAg-positive patients who underwent liver transplantation between 1977 and 1990. Recurrence of HBV infection was defined as the reappearance of $\mathrm{HBsAg}$ in serum.

Results. For all 334 patients with follow-up data, the mean $( \pm S E)$ three-year actuarial risk of recurrence of HBV was $50 \pm 3$ percent. The risk was $67 \pm 4$ percent among 163 patients with HBV-related cirrhosis, $32 \pm 5$ percent among 110 patients with cirrhosis related to hepatitis delta virus, $40 \pm 16$ percent among 14 patients with fulminant hepatitis delta infection, and $17 \pm 7$ percent among 39 patients with fulminant $H B V$ infection $(P<0.001)$. Among the patients with HBV-related cirrhosis, the risk of HBV recurrence was greatest $(83 \pm 6$ percent) in those who were seropositive for HBV DNA at the time of transplanta-
\end{abstract}

$\mathrm{L}^{\mathrm{I}}$ IVER transplantation is an established treatment for life-threatening liver disease, and patients with chronic or acute liver failure due to hepatitis B virus (HBV) infection represent a large pool of candidates for liver transplantation. ${ }^{1,2}$ However, numerous reports describe a high rate of recurrence of $\mathrm{HBV}$ infection after liver transplantation, with severe graft disease $\mathrm{e}^{3-5}$ and decreased survival of patients and grafts. ${ }^{6-10}$ The role of liver transplantation in patients positive for hepatitis B surface antigen (HBsAg) remains controversial, especially in patients with active HBV replication (i.e., those seropositive for the hepatitis B e antigen [HBeAg], HBV DNA, or both). ${ }^{11}$ Many attempts to prevent HBV infection of the graft have been described, including short-term ${ }^{10,12-14}$ and long-term ${ }^{15-18}$ administration of polyclonal anti-hepatitis B surface antigen (anti-HBs) immune globulin, administration of monoclonal anti-HBs immune globulin, ${ }^{19}$ active immunoprophylaxis, ${ }^{20}$ antiviral therapy, ${ }^{21}$ and a combination of these treatments. ${ }^{22}$

From the Hepatobiliary Surgery and Liver Transplantation Research Unit, Paul Brousse Hospital, Villejuif, France (D.S., H.B.); Abteilung Gastroenterologie und Hepatologie, Medizinische Hochschule Hannover, Hannover, Germany (R.M.); the Department of Medicine, Addenbrooke's Hospital, Cambridge, United Kingdom (G.A.); Centro Trapianti, Ospedale Policlinico, Istituto Ricovero e Curá a Caràttere Scientifico, Milan, Italy (L.F.); INSERM U 292, Le Kremlin-Bicêtre, France (B.D.); and Service d'Hépatologie, Hôpital Beaujon, Clichy, France (J.-P.B.). Address reprint requests to Dr. Samuel at the Hepatobiliary Surgery and Liver Transplantation Research Unit, Paul Brousse Hospital, 14 Av. PV Couturier, 94800-Villejuif, France.

*The investigators and institutions participating in the European Concerted Action on Viral Hepatitis (EUROHEP) study are listed in the Appendix. tion and lowest $(58 \pm 7$ percent) in those with neither HBV DNA nor hepatitis $B$ e antigen detectable in serum. With respect to the use of passive prophylaxis with anti-HBs immune globulin, the risk of HBV recurrence was $75 \pm 6$ percent among the 67 patients given no immunoprophylaxis, $74 \pm 5$ percent among the 83 treated for two months, and $36 \pm 4$ percent among the 209 treated for six months or longer $(P<0.001)$. In a multivariate analysis the predictors of a lower risk of HBV recurrence were the long-term administration of the immune globulin, hepatitis delta virus superinfection, and acute liver disease. For the entire study cohort, survival was 75 percent at one year and 63 percent at three years, but for those in whom HBV infection recurred, survival was 68 percent at one year and 44 percent at three years.

Conclusions. In this retrospective study of HBsAgpositive patients, liver transplantation had better results in those who had fulminant hepatitis or delta virus superinfection. An absence of viral replication at the time of transplantation and long-term immunoprophylaxis were associated with a reduced risk of recurrent HBV infection and reduced mortality. (N Engl J Med 1993;329: 1842-7.)

Recently, encouraging reports have described the use of long-term passive anti-HBs immunoprophylaxis, especially in patients seronegative for HBV DNA. ${ }^{16,17}$

As part of the European Concerted Action on Viral Hepatitis (EUROHEP) project, ${ }^{23}$ we evaluated the results of liver transplantation in $\mathrm{HBsAg}$-positive patients in European centers to determine the factors that predict $\mathrm{HBV}$ recurrence and survival after liver transplantation and to assess the effects of passive anti-HBs immunoprophylaxis on recurrence and survival.

\section{MethodS}

\section{Patients}

A questionnaire was sent in March 1990 to the 69 liver-transplant centers that were members of the European Liver Transplant Registry, ${ }^{1}$ asking for data on all $\mathrm{HBsAg}$-positive patients who had undergone liver transplantation as of that date. The following data were requested for each patient: age and sex; the type of liver disease diagnosed; status for $\mathrm{HBV}$ and hepatitis delta virus (HDV) before transplantation (indicated by the presence of HBV DNA detected by standard molecular hybridization technique and the presence in serum of $\mathrm{HBsAg}, \mathrm{HBeAg}$, antibody to $\mathrm{HBeAg}, \mathrm{HDV}$ antigen, or antibody to HDV); methods used to prevent HBV reinfection before, during, and after transplantation (details on the use of polyclonal or monoclonal anti-HBs immune globulin, active anti-HBs immunization, and other antiviral therapy); date of reappearance of $\mathrm{HBsAg}$ and HBV DNA; current status for HBV; current status of the graft; duration of follow-up; dates of and reasons for repeated transplantation; and date and cause of death. Eighteen centers replied to the questionnaire. All $\mathrm{HBsAg}$-positive patients undergoing transplantation at each center from the initiation of a program of liver transplantation at the center to March 1990 were described by the centers and included in this study. A 
second questionnaire was sent in June 1991 to 17 of the centers (the center in Helsinki, Finland, reported that no HBsAg-positive patients had undergone transplantation) to update to June 1991 follow-up data on the patients already included.

$\mathrm{HBV}$ recurrence was defined as the reappearance of $\mathrm{HBsAg}$ in serum. With respect to the administration of anti-HBs immune globulin, patients were classified into three groups: those who received no immune globulin at all (no immunoprophylaxis), those who received it for less than six months after liver transplantation (short-term therapy), and those who received it for at least six months after transplantation (long-term therapy). In each group, some patients died before completing the course of immunoprophylaxis. These patients were included in the analyses according to the intention-to-treat principle.

\section{Statistical Analysis}

Statistical analyses were performed with a BMDP statistical software package. ${ }^{24}$ Means were compared by analysis of variance. All patients were followed for the recurrence of $\mathrm{HBV}$ from the date of transplantation to death, documentation of positivity for $\mathrm{HBsAg}$, or the last disease-free visit. Follow-up for survival analysis began on the date of liver transplantation and continued until death or the last visit. The status of all patients was updated by each center in June 1991. Patients who received a second transplant, whether or not they had had a recurrence of $\mathrm{HBV}$, were included in the analysis until their death or last visit. Survival and the recurrence rate for HBV infection were calculated with actuarial life-table analyses. Survival curves were compared by the log-rank test. Multivariate analyses were performed with the Cox model (with the Wald test for assessing the effect of the entered variables on survival and recurrence rates for $\mathrm{HBsAg}$ and for calculating the relative risks of death and $\mathrm{HBV}$ recurrence). The following variables were entered in the multivariate analyses: anti-HBs immune globulin treatment (longterm therapy vs. short-term therapy vs. no immunoprophylaxis), year of liver transplantation (before 1986, 1986, 1987, 1988, and 1989), course of liver disease (acute vs. chronic disease; acute disease included fulminant HBV and fulminant HDV, and chronic disease included $\mathrm{HBV}$-related and HDV-related cirrhosis), serologic status for HBV DNA before liver transplantation (presence vs. absence), serologic status for $\mathrm{HBeAg}$ before transplantation (presence vs. absence), and superinfection with hepatitis (HDV vs. nonHDV; HDV superinfection included HDV-related cirrhosis and fulminant HDV; non-HDV superinfection included $\mathrm{HBV}$-related cirrhosis and fulminant $\mathrm{HBV}$ ).

\section{Results}

Liver transplantation was performed in 372 consecutive HBsAg-positive patients between 1977 and March 1990 at 17 centers. The patients' diagnoses are shown in Table 1. Among the 201 patients with HBVrelated cirrhosis, the pretransplantation status for HBV DNA was known in 163 (58 were seropositive and 105 seronegative). The pretransplantation status for $\mathrm{HBeAg}$ was known in 191 patients ( 73 were seropositive and 118 seronegative). The mean ( $\pm \mathrm{SE}$ ) length of follow-up in the 372 patients was $24.8 \pm 19$ months.

At the end of follow-up, the post-transplantation status for HBsAg was known in 334 of the 372 patients: 176 (52.7 percent) were seronegative for HBsAg, and 158 (47.3 percent) were seropositive. - Among all patients, the actuarial risk of recurrence of HBV after transplantation was $40 \pm 3$ percent at one year and $50 \pm 3$ percent at three years. The three-year actuarial risk of $\mathrm{HBV}$ recurrence after transplantation was $67 \pm 4$ percent in the patients with $\mathrm{HBV}$-related cirrhosis, $32 \pm 5$ percent in those with HDV-related
Table 1. Initial Liver Disease of the $372 \mathrm{~Pa}$ tients Studied and Their Serologic Status for HBV DNA at the Time of Transplantation.

\begin{tabular}{|c|c|}
\hline $\begin{array}{l}\text { Disease/HBV } \\
\text { DNA Status }\end{array}$ & $\begin{array}{c}\text { No. of } \\
\text { Patients }\end{array}$ \\
\hline HBV-related cirnhosis & 201 \\
\hline HBV DNA + & 58 \\
\hline $\mathrm{HBeAg}+$ & 33 \\
\hline $\mathrm{HBeAg}-$ & 23 \\
\hline Unknown & 2 \\
\hline HBV DNA - & 105 \\
\hline $\mathrm{HBeAg}+$ & 27 \\
\hline $\mathrm{HBeAg}-$ & 72 \\
\hline Unknown & 6 \\
\hline HBV DNA unknown & 38 \\
\hline $\mathrm{HBeAg}+$ & 13 \\
\hline $\mathrm{HBeAg}-$ & 23 \\
\hline Unknown & 2 \\
\hline Fulminant HBV & 39 \\
\hline HBV DNA+ & 0 \\
\hline HBV DNA - & 29 \\
\hline Unknown & 10 \\
\hline HDV-related cirrhosis & 110 \\
\hline HBV DNA + & 3 \\
\hline HBV DNA - & 100 \\
\hline Unknown & 7 \\
\hline Fulminant HDV & 14 \\
\hline HBV DNA + & 2 \\
\hline HBV DNA- & 8 \\
\hline Unknown & 4 \\
\hline Other diseases* & 8 \\
\hline
\end{tabular}

*Hepatocellular carcinoma and HBV in six patients, hepatocellular carcinoma and HDV in one, and various liver diseases in one.

cirrhosis, $40 \pm 16$ percent in those with fulminant $\mathrm{HDV}$, and $17 \pm 7$ percent in those with fulminant $\mathrm{HBV}$ $(\mathrm{P}<0.001)$ (Fig. 1). Among the patients with HBVrelated cirrhosis, the three-year actuarial risk of

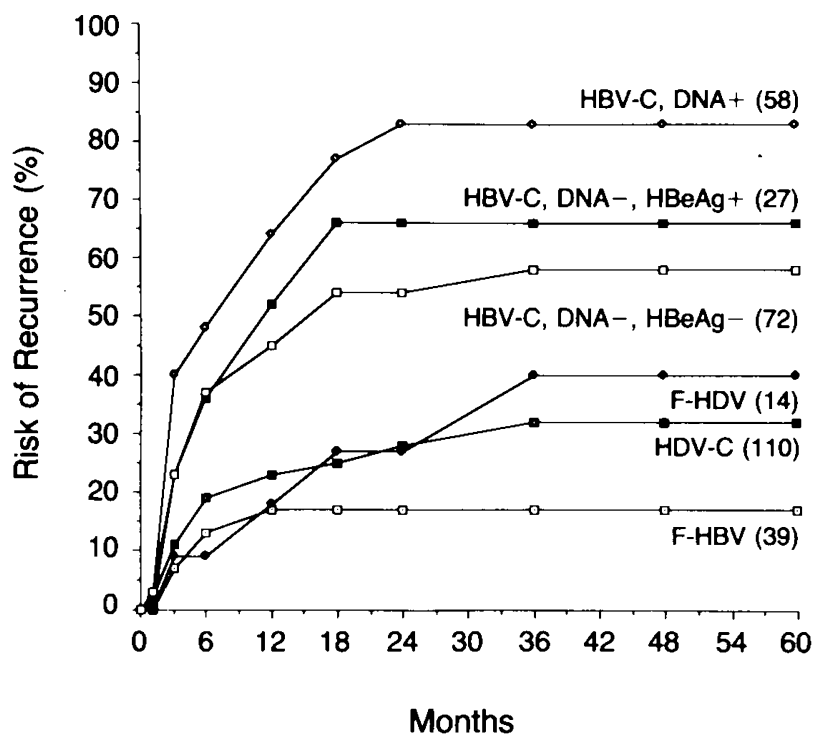

Figure 1. Actuarial Risk of Recurrence of HBV Infection as Indicated by the Reappearance of HBsAg, According to Initial Liver Disease and Pretransplantation Viral-Replication Status.

HBV-C denotes HBV-related cirrhosis, F-HDV fulminant HDV, HDV-C HDV-related cirrhosis, and F-HBV fulminant HBV. Values in parentheses denote numbers of patients. DNA + denotes the presence of HBV DNA, and DNA- its absence. 
HBV recurrence was $83 \pm 6$ percent in those seropositive for HBV DNA, $66 \pm 10$ percent in those seronegative for HBV DNA and seropositive for $\mathrm{HBeAg}$, and $58 \pm 7$ percent in those seronegative for HBV DNA and HBeAg $(P=0.05)$ (Fig. 1$)$.

Information on the administration of anti-HBs immune globulin during or after transplantation was available for 359 patients. This treatment was given to 292 patients: 209 received long-term therapy, 83 received short-term therapy, and 67 received no immunoprophylaxis. The protocols for immunoprophylaxis differed among centers and within them. Patients given short-term therapy did not receive the agent for more than two months after transplantation, and patients given long-term therapy received it for six months, for one year, or indefinitely. Both these groups received immune globulin either on a routine basis or in relation to their serum anti-HBs titer; the mean amount given each group at two months cannot be calculated from data collected for this study. The actuarial risk of $\mathrm{HBV}$ recurrence after transplantation in relation to the duration of treatment with anti-HBs immune globulin is shown in Figure 2. There was no difference in risk between the patients given no therapy and those given short-term therapy, but there was a substantial reduction of risk in the patients given long-term therapy $(\mathrm{P}<0.001)$. The mean time to HBV recurrence after liver transplantation was $3.2 \pm 2.7$ months in patients not given immunoprophylaxis, $3.0 \pm 2.6$ months in those given short-term therapy, and 8.6 \pm 6.8 months in those given long-term therapy $(\mathbf{P}<0.001)$. For patients with HBV-related cirrhosis, the three-year actuarial risk of $\mathrm{HBV}$ recurrence after transplantation was $78 \pm 8$ percent, $90 \pm 6$ percent, and $56 \pm 6$ percent among the 29 patients not given immunoprophylaxis, the 37 given short-term therapy, and the 100 given long-term therapy, respectively $(\mathbf{P}<0.001)$. For patients with HDV-related cirrhosis, the three-year actuarial risk of HBV recurrence after transplantation was $70 \pm 14$ percent, $56 \pm 10$ percent, and $17 \pm 6$ percent among the 10 patients given no immunoprophylaxis, the 25 given short-term therapy, and the 66 given long-term therapy, respectively $(\mathrm{P}<0.001)$. Among patients with HBV-related or HDV-related cirrhosis, there was no significant difference between the group given no immunoprophylaxis and the group given short-term therapy, but there was a significant difference between these groups combined and the group given long-term therapy $(\mathbf{P}<0.001)$. Among patients with fulminant HBV, the three-year actuarial risk of recurrence of $\mathrm{HBV}$ after transplantation was $58 \pm 22$ percent in the 6 patients given no immunoprophylaxis and 0 percent in the 24 given long-term therapy (the number of patients given short-term therapy was too small to permit analysis). The three-year actuarial risk of HBV recurrence after transplantation was $34 \pm 16$ percent among the $11 \mathrm{pa}$ tients with fulminant HDV who were given long-term therapy (this group was not compared with the two other groups because the number of patients in whom an effect could be identified was too small). Because

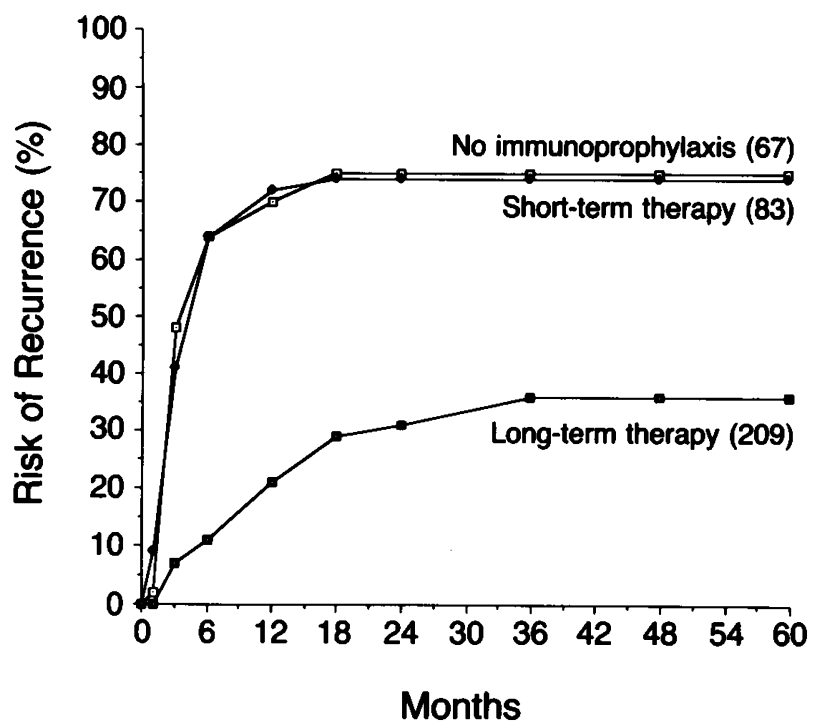

Figure 2. Actuarial Risk of Recurrence of HBV, According to the Duration of Passive Prophylaxis with Anti-HBs Immune Globulin. The risk of recurrence in the group given long-term therapy was significantly lower than in either of the other groups $(P<0.001)$. Values in parentheses denote numbers of patients.

little information was available on the use of antiviral agents, active immunization against $\mathrm{HBsAg}$, and histologic analysis of the graft, these variables could not be included in the analyses.

In a univariate analysis that included all patients, the factors predictive of a lower risk of $\mathrm{HBV}$ recurrence after liver transplantation were the presence of HDV superinfection (fulminant HDV or HDV-related cirrhosis) $(\mathrm{P}<0.001)$, the presence of an acute liver disease $(\mathrm{P}<0.001)$, long-term administration of antiHBs immune globulin $(P<0.001)$, the absence of HBV DNA before liver transplantation $(P<0.001)$, and the absence of $\mathrm{HBeAg}$ before transplantation $(P<0.001)$. In a multivariate analysis, the independent predictors of a lower risk of HBV recurrence after liver transplantation were long-term administration of anti-HBs immune globulin (relative risk, 3.28; 95 percent confidence interval, 1.92 to $5.60 ; \mathrm{P}<0.001$ ), HDV superinfection (relative risk, 3.92; 95 percent confidence interval, 2.48 to $6.21 ; \mathrm{P}<0.001$ ), and acute liver disease (relative risk, 3.76; 95 percent confidence interval, 1.70 to $8.30 ; \mathrm{P}<0.001)$. In patients undergoing transplantation for HBV-related cirrhosis, the independent predictors of a lower risk of HBV recurrence after liver transplantation were long-term administration of immune globulin (relative risk, 2.63; 95 percent confidence interval, 1.39 to $4.96 ; \mathrm{P}<0.01$ ), the absence of HBV DNA in serum before transplantation (relative risk, 1.67; 95 percent confidence interval, 1.10 to 2.54; $\mathrm{P}<0.05)$, and the absence of $\mathrm{HBeAg}$ in serum before transplantation (relative risk, ${ }^{\circ} 2.05$; 95 percent confidence interval, 1.33 to $3.14 ; \mathrm{P}<0.001$ ).

Survival of all patients at one year and three years was $75 \pm 2$ percent and $63 \pm 3$ percent, respectively. The actuarial one-year survival of patients undergoing transplantation before 1986, in 1986, in 1987, in 
1988 , and in 1989 was $39 \pm 8$ percent, $57 \pm 8$ percent, $78 \pm 5$ percent, $77 \pm 4$ percent, and $83 \pm 3$ percent, respectively $(P<0.001)$. The actuarial survival of patients in relation to their initial liver disease (fulminant HBV, fulminant HDV, HBV-related cirrhosis, or HDV-related cirrhosis) is shown in Figure 3; the differences among these four groups were significant $(\mathrm{P}<0.001)$. The actuarial survival of patients receiving no immunoprophylaxis, short-term therapy, and long-term therapy is shown in Figure 4. Actuarial survival at one year and three years was 73 percent and 54 percent, respectively, among patients with HBV recurrence and 90 percent and 83 percent, respectively, among those who remained $\mathrm{HBsAg}$-negative.

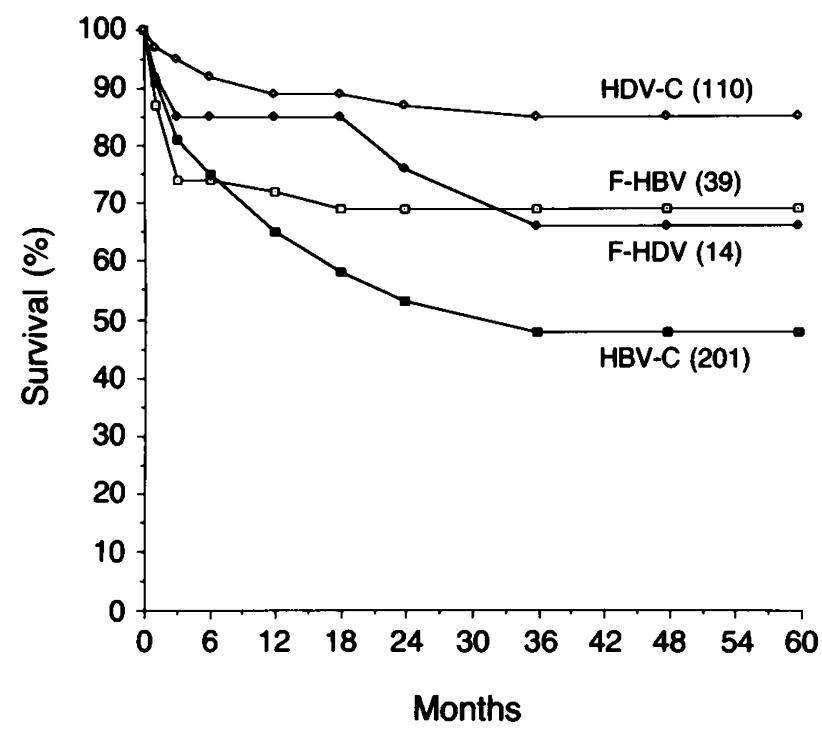

Figure 3. Actuarial Survival, According to Initial Liver Disease. HDV-C denotes HDV-related cirrhosis, F-HBV fulminant HBV, F-HDV fulminant HDV, and HBV-C HBV-related cirrhosis. The differences in survival between these groups were significant $(P<0.001)$. Values in parentheses denote numbers of patients.

The survival curves differed significantly $(P<0.001)$. Among patients with recurrence of $\mathrm{HBV}$, actuarial survival at one year and three years was 68 percent and 44 percent, respectively, among those undergoing transplantation for HBV-related cirrhosis and 86 percent and 83 percent, respectively, among those undergoing transplantation for HDV-related cirrhosis $(\mathrm{P}<0.001)$. In a univariate analysis, the presence of HDV superinfection (fulminant HDV or HDV-related cirrhosis) $(\mathbf{P}<0.001)$, long-term administration of anti-HBs immune globulin $(\mathbf{P}<0.001)$, the absence of HBV DNA before liver transplantation $(\mathrm{P}<0.001)$, and the absence of $\mathrm{HBeAg}$ before transplantation $(P=0.05)$ were predictive of better survival. In a multivariate analysis, long-term administration of anti-HBs immune globulin (relative risk, 2.22; 95 percent confidence interval, 1.13 to $4.33 ; \mathrm{P}<0.001$ ) and HDV superinfection (relative risk, 6.25; 95 percent confidence interval, 3.13 to $12.42 ; \mathrm{P}<0.001$ ) were independently predictive of better survival among all patients studied. Long-term administration of immune globulin (relative risk, 2.41; 95 percent confidence interval, 1.06 to $5.48 ; \mathrm{P}<0.05$ ) was independently predictive of better survival among patients with HBV-related cirrhosis.

A second transplantation was performed in 42 of the 372 patients ( 11 percent), of whom 10 (23.8 percent) were alive at the most recent follow-up. Nineteen patients underwent transplantation again because of HBV infection of the graft a mean of $10.1 \pm 8.4$ months after their first transplantation. Of these 19 patients, 6 died in the perioperative period of various causes not related to $\mathrm{HBV}, 7$ died because of $\mathrm{HBV}$ reinfection of the second graft ( 2 of them after their second repeat transplantation), and 6 were alive at the most recent follow-up. The mean time from the first repeat transplantation to death or a second transplantation for HBV reinfection was $3.3 \pm 1.8$ months.

Forty of the 372 patients (10.8 percent) died as a direct result of recurrence of $\mathrm{HBV}$, with a mean survival of $12.0 \pm 7.2$ months (range, 0.5 to 30 ). Thirtyone (15.4 percent) of the 201 patients with HBV-related cirrhosis died of recurrence of $\mathrm{HBV}$, as compared with 3 (2.7 percent) of the 110 with HDV-related cirrhosis, 2 (14.3 percent) of the 14 with fulminant hepatitis HDV, and none of those with fulminant HBV.

\section{Discussion}

Liver transplantation in $\mathrm{HBsAg}$-positive patients remains controversial. ${ }^{2,7,11}$ Some centers consider the presence of HBsAg a contraindication to transplantation, and most centers are reluctant to perform the procedure if HBV replication is ongoing. Our study offers an opportunity to analyze the results of liver transplantation in the largest series of $\mathrm{HBsAg}$-positive patients ever to our knowledge described. The inclu-

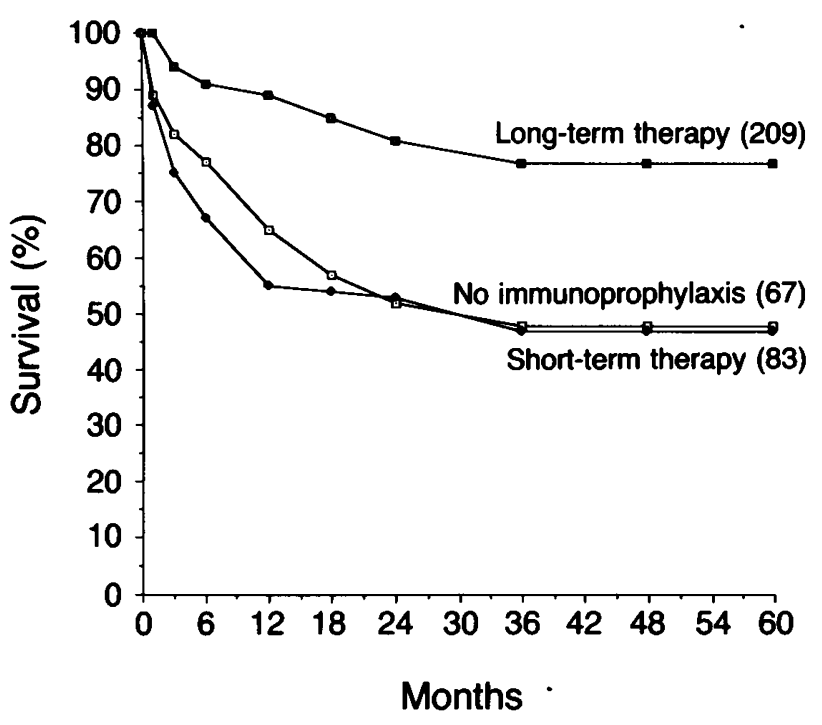

Figure 4. Actuarial Survival, According to the Duration of Passive Prophylaxis with Anti-HBs Immune Globulin.

Survival in the group given long-term therapy was significantly better than in either of the other groups $(P<0.001)$. Values in parentheses denote numbers of patients. 
sion of 17 European centers permitted us to compare outcomes in relation to initial liver disease and to compare the results of the use of anti-HBs passive immunoprophylaxis on the rate of infection of the graft with $\mathrm{HBV}$ and on survival. However, this study is retrospective, which may be a limiting factor in the analysis.

The main finding of this study was that $372 \mathrm{HBsAg}$ positive liver recipients had an actuarial survival of 75 percent at one year and 63 percent at three years, and that the overall actuarial risk of $\mathrm{HBV}$ recurrence was 50 percent.

The three-year actuarial risk of recurrence of $\mathrm{HBsAg}$ was significantly higher among patients undergoing transplantation for $\mathrm{HBV}$-related cirrhosis (67 percent) than among those undergoing transplantation for HDV-related cirrhosis (32 percent) or fulminant HBV (17 percent) (Fig. 1). These results agree with those of previous studies, which showed that the type of liver disease at presentation influenced the rate of recurrence of HBV., ${ }^{8,10,16,17}$ This study also confirms the effect of HBV replication before transplantation on the risk of recurrence after transplantation. The three-year actuarial risk of recurrence of HBV infection among patients with HBV-related cirrhosis who were seropositive for HBV DNA before transplantation was 83 percent, as compared with 66 percent among those seronegative for HBV DNA and seropositive for $\mathrm{HBeAg}$, and 58 percent in those seronegative for both HBV DNA and $\mathrm{HBeAg}(\mathrm{P}<0.05)$. Univariate analysis demonstrated that the presence of $\mathrm{HBV}$ DNA or $\mathrm{HBeAg}$ before transplantation, irrespective of the type of liver disease, was a factor predictive of recurrence of $\mathrm{HBV}$. Multivariate analysis demonstrated that these two markers of HBV replication appeared to be independent predictive factors of recurrence among patients undergoing transplantation for HBV-related cirrhosis. In a previous study, Samuel et al. showed that HBV DNA was a prognostic indicator of recurrence of $\mathrm{HBV}$ in patients undergoing transplantation for HBV-related cirrhosis, but that a patient's status for HBeAg was not such an indicator. ${ }^{16}$ However, other reports indicated that $\mathrm{HBeAg}$ status had a role as a marker of recurrence of HBV after transplantation. ${ }^{10,17}$ It is clear from the present study that a patient's status for HBV replication, determined either by a simple hybridization technique for HBV DNA or by serologic examination for $\mathrm{HBeAg}$, is important for predicting $\mathrm{HBV}$ recurrence. Both markers of $\mathrm{HBV}$ replication should be determined since many patients, especially those in Mediterranean areas, are positive for the antibody to $\mathrm{HBeAg}$ as well as for $\mathrm{HBV}$ DNA. ${ }^{25,26}$

In contrast, the three-year actuarial recurrence rate of $\mathrm{HBV}$ infection was much lower among patients undergoing transplantation for fulminant HDV, HDV-related cirrhosis, or fulminant HBV (40 percent, 32 percent, and 17 percent, respectively) (Fig. 1). The lower risk of recurrence among the patients with HDV-related cirrhosis could be explained by the seronegativity for HBV DNA in most of these patients before transplantation and by the inhibitory effect of HDV on HBV replication. ${ }^{9,27}$ The lower risk of HBV recurrence among the patients with fulminant HBV could be explained by the absence of detectable $\mathrm{HBV}$ replication according to molecular hybridization studies at the time of transplantation in most patients. ${ }^{28}$ The three-year actuarial risk of HBV recurrence among patients with fulminant HDV was 40 percent, higher than the risk among patients with fulminant $\mathrm{HBV}$. There is no clear explanation for this finding; we could not differentiate patients with HDV superinfection from those coinfected with $\mathrm{HBV}$ and HDV.

A second finding of this study was that anti-HBs immune globulin had a significant effect on the risk of HBV recurrence after transplantation. The patients given long-term therapy with this agent had a significant overall reduction in HBV recurrence, as compared with the patients given short-term therapy and those given no immunoprophylaxis (Fig. 2). Interestingly, there was no difference in the risk of HBV recurrence between the two latter groups (Fig. 2). In addition, long-term administration of immune globulin significantly reduced the recurrence of $\mathrm{HBV}$ after transplantation in three groups of patients with different types of liver disease - HBV-related cirrhosis, HDV-related cirrhosis, and fulminant HBV. The efficacy of long-term treatment with anti-HBs immune globulin had been suggested by several nonrandomized studies from Paris, Hannover, and Berlin. ${ }^{16-18}$ In contrast, investigators who gave patients either no immunoprophylaxis ${ }^{6,8,10}$ or short-term immunoprophylaxis ${ }^{10,13,14}$ observed a high risk of HBV recurrence about 80 percent. The beneficial effect of long-term passive prophylaxis with anti-HBs immune globulin supports the hypothesis that reinfection of the graft with $\mathrm{HBV}$ is related to the presence and replication of this virus in extrahepatic sites. ${ }^{29-31}$ It should be emphasized that most cases of HBV reinfection occurred during the first year after transplantation. The marked difference in the risk of HBV recurrence at three months between the group given long-term therapy and the group given short-term therapy could be due to the higher amount of anti-HBs immune globulin administered to the former group and to the discontinuation of this drug in the latter group two months after transplantation. In the group receiving long-term immunoprophylaxis, most cases of HBV reinfection occurred during the first year after transplantation, and a few cases occurred after two years (Fig. 2). This interesting observation raises questions about the proper duration of anti-HBs passive immunoprophylaxis. In this study, some investigators discontinued the therapy six months or one year after transplantation, and some groups continued it indefinitely. The issue of whether therapy can be discontinued after one year or two years should be addressed.

Our study showed that overall actuarial survival among HBsAg-positive patients one year and three years after liver transplantation was 75 percent and 63 percent, respectively. As among patients undergoing 
the procedure for other indications, outcome has improved continuously, with one-year survival of 57 percent and 83 percent of patients undergoing transplantation in 1986 and 1989 , respectively. It is difficult to determine whether this improvement is related to improvement in the techniques of liver transplantation or to greater use of anti-HBs passive immunoprophylaxis in recent years, as suggested by Figure 4. We think that both factors are relevant. In this series of patients, 10.8 percent died of graft infection with $\mathrm{HBV}$, which occurred more frequently in patients undergoing transplantation for $\mathrm{HBV}$-related cirrhosis than in those undergoing it for HDV-related cirrhosis or fulminant $\mathrm{HBV}$; this higher frequency may be due to the higher risk of $\mathrm{HBV}$ reinfection among patients with HBV-related cirrhosis but also - intriguingly - to a more severe course of $\mathrm{HBV}$ reinfection in this group. Thus, it is very important to long-term outcome that patients remain HBsAg-negative after transplantation, since the overall actuarial survival at one year and three years was significantly higher among patients who remained negative for $\mathrm{HBsAg}$ (90 percent and 83 percent, respectively) than among those who became HBsAg-positive again (73 percent and 54 percent, respectively).

We are indebted to Professor Solko W. Schalm, Project Leader of EUROHEP.

\section{Appendix}

The following investigators and institutions were members of the EUROHEP Study Group on Hepatitis B Virus and Liver Transplantation: Hospital Universitario "Princeps D'Espanya," Barcelona, Spain - T. Casanovas and E. Jaurrieta; Universitätsklinikum Rudolf Virchow, Berlin, Germany - G. Blumhardt and P. Neuhaus; Queen Elizabeth Hospital, Birmingham, United Kingdom J. Neuberger and P. McMaster; Hôpital Saint Andre, Bordeaux, France - J. Saric and S. Winnock; Université Catholique de Louvain, Brussels, Belgium - J. Lerut and B. Otte; Addenbrooke's Hospital, Cambridge, United Kingdom - G. Alexander and R.Y. Calne; S. Martino Hospital, Genoa, Italy - M. Bertocchi and R. Pellicci; Chirurgische Universität Klinik, Hamburg, Germany - B. Kremer; Medizinische Hochschule Hannover, Hannover, Germany - B. Ringe and R. Pichlmayr; King's College Hospital, London - J.G. O'Grady and R. Williams; Hospital "12 de Octubre," Madrid, Spain - E. Moreno-Gonzales and C. Loinaz Segurola; Istituto Ricovero e Curá a Caràttere Scientifico, Milan, Italy - L.R. Fassati and D. Galmarini; Chirurgische Klinik und Poliklinik der Technischen Universität, Munich, Germany J. Adolf; Services de Chirurgie et d'Hépatologie, Hôpital Bicêtre, Kremlin-Bicêtre, France - O. Bernard and J. Valayer; Paul Brousse Hospital, Villejuif, France - H. Bismuth and D. Samuel; University Hospital Rotterdam, Rotterdam, the Netherlands H.J. Metselaar and S.W. Schalm; and University Hospital, Zurich, Switzerland - M. Decurtins and R. Schlumpf.

Executive Team of EUROHEP on liver transplantation: G. Alexander, J.P. Benhamou, H. Bismuth, L.R. Fassati, R. Muller, and D. Samuel.

\section{REFERENCES}

1. Bismuth H, Castaing D, Ericzon BG, et al. Hepatic transplantation in Europe: First Report of the European Liver Transplant Registry. Lancet 1987;2:674-6. [Erratum, Lancet 1987;2:1414.]

2. Starzl TE, Demetris AJ, Van Thiel D. Liver transplantation. N Engl J Med 1989;321:1092-9.

3. Demetris AJ, Jaffe R, Sheahan DG, et al. Recurrent hepatitis B in liver allograft recipients: differentiation between viral hepatitis $B$ and rejection. Am J Pathol 1986;125:161-72.

4. Demetris AJ, Todo S, Van Thiel DH, et al. Evolution of hepatitis B virus liver disease after hepatic replacement: practical and theoretical considerations. Am J Pathol 1990;137:667-76.
5. Davies SE, Portmann BC, O'Grady JG, et al. Hepatic histological findings after transplantation for chronic hepatitis B virus infection, including a unique pattern of fibrosing cholestatic hepatitis. Hepatology 1991;13:1507.

6. Freeman RB, Sanchez H, Lewis WD, et al. Serologic and DNA follow-up data from HBsAg-positive patients treated with orthotopic liver transplantation. Transplantation 1991;51:793-7.

7. Lake JR, Wright TL. Liver transplantation for patients with hepatitis B: what have we learned from our results? Hepatology 1991;13:796-9.

8. O'Grady JG, Smith HM, Davies SE, et al. Hepatitis B virus reinfection after orthotopic liver transplantation: serological and clinical implications. J Hepatol 1992;14:104-11.

9. Rizzetto M, Recchia S, Salizzoni M. Liver transplantation in carriers of the HBsAg. J Hepatol 1991;13:5-7.

10. Todo S, Demetris AJ, Van Thiel D, Teperman L, Fung J, Starzl TE. Orthotopic liver transplantation for patients with hepatitis B virus-related liver disease. Hepatology 1991;13:619-26.

11. Van Thiel DH, Schade RR, Gavaler JS, Shaw BW Jr, Iwatsuki S, Starzl TE. Medical aspects of liver transplantation. Hepatology 1984;4:Suppl:79S83S.

12. Johnson PJ, Wansbrough-Jones MH, Portmann B, et al. Familial HBsAgpositive hepatoma: treatment with orthotopic liver transplantation and specific immunoglobulin. BMJ 1978;1:216.

13. Lauchart W, Müller R, Pichlmayr R. Immunoprophylaxis of hepatitis B virus reinfection in recipients of human liver allografts. Transplant Proc 1987; 19:2387-9.

14. Mora NP, Klintmalm GB, Poplawski SS, et al. Recurrence of hepatitis B after liver transplantation: does hepatitis-B-immunoglobulin modify the recurrent disease? Transplant Proc 1990;22:1549-50.

15. Lauchart W, Müller R, Pichlmayr R. Long-term immunoprophylaxis of hepatitis $B$ virus reinfection in recipients of human liver allografts. Transplant Proc 1987;19:4051-3.

16. Samuel D, Bismuth A, Mathieu D, et al. Passive immunoprophylaxis after liver transplantation in HBsAg-positive patients. Lancet 1991;337:8135.

17. Müller R, Gubernatis $G$, Farle $M$, et al. Liver transplantation in HBs antigen (HBsAg) carriers: prevention of hepatitis B virus (HBV) recurrence by passive immunization. J Hepatol 1991;13:90-6.

18. Hopf $U$, Neuhaus $P$, Lobeck $H$, et al. Follow-up of recurrent hepatitis $B$ and delta infection in liver allograft recipients after treatment with recombinant interferon- $\alpha$. J Hepatol 1991;13:339-46.

19. Fung J, Ostberg L, Shapiro R, Todo S, Demetris A, Starzl TE. Human monoclonal antibody against hepatitis $B$ surface antigen in preventing recurrent hepatitis $B$ following liver transplantation. In: Hollinger FB, Lemon SM, Margolis HS, eds. Viral hepatitis and liver disease. Baltimore: Williams \& Wilkins, 1991:651.

20. Colledan M, Gislon M, Doglia M, et al. Liver transplantation in patients with B viral hepatitis and delta infection. Transplant Proc 1987;19:40736.

21. Lavine JE, Lake JR, Ascher NL, Ferrell LD, Ganem D, Wright TL. Persistent hepatitis $B$ virus following interferon alfa therapy and liver transplantation. Gastroenterology 1991;100:263-7.

22. Marcellin P, Samuel D, Areias J, Gigou M, Benhamou JP, Bismuth $H$. Effect of pre-transplant recombinant alpha interferon treatment on HBV reinfection in patients with cirrhosis B. Hepatology 1991;14:Suppl:71A. abstract.

23. Schalm SW. EUROHEP: a European Community sponsored concerted action on viral hepatitis: its rationale and execution. J Hepatol 1992;15:1-3.

24. Dixon WJ, Brown MB, Engelman L, Jennrich RI, eds. BMDP statistical software manual. Berkeley: University of California Press, 1990.

25. Hadziyannis SJ, Lieberman HM, Karvountzis GG, Shafritz DA. Analysis of liver disease, nuclear $\mathrm{HBcAg}$, viral replication, and hepatitis B virus DNA in liver and serum of HBeAg Vs. anti-HBe positive carriers of hepatitis B virus. Hepatology 1983;3:656-62.

26. Bonino F, Rosina F, Rizzetto M, et al. Chronic hepatitis in HBsAg carriers with serum HBV-DNA and anti-HBe. Gastroenterology 1986;90:126873.

27. Krogsgaard K, Kryger P, Aldershvile J, Andersson P, Sorensen TI, Nielsen JO. Delta infection and suppression of hepatitis B virus replication in chronic HBsAg carriers. Hepatology 1987;7:42-5.

28. Brechot C, Bernuau J, Thiers $\mathrm{V}$, et al. Multiplication of hepatitis $B$ virus in fulminant hepatitis B. BMJ 1984;288:270-1.

29. Feray C, Zignego AL, Samuel D, et al. Persistent hepatitis B virus infection of mononuclear blood cells without concomitant liver infection: the liver transplantation model. Transplantation 1990;49:1155-8.

30. Zignego AL, Samuel D, Gugenheim J, et al. Hepatitis B virus replication and mononuclear blood cell infection after liver transplantation. In: Zuckermann AJ, ed. Viral hepatitis and liver disease: proceedings of the International Symposium on Viral Hepatitis and Liver Disease held at the Barbican Centre, London, May 26-28, 1987. New York: Alan R. Liss, 1988:8089.

31. Yoffee $B$, Müller R. Liver transplantation in patients with $H B V$ infection: implications of extra-hepatic $\mathrm{HBV}$ infection. In: Hollinger FB, Lemon SM, Margolis HS, eds. Viral hepatitis and liver disease. Baltimore: Williams \& Wilkins, 1991:813-9. 